\title{
Clean Cities Annual Metrics Report 2006
}

Technical Report NREL/TP-540-41753 July 2007

P. Bergeron and V. Putsche

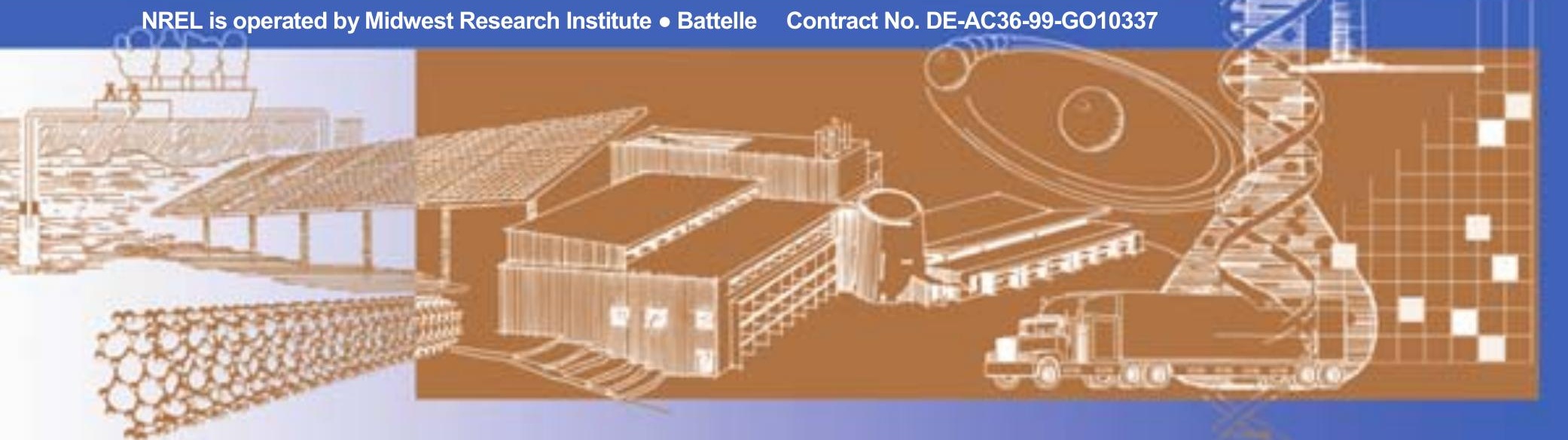




\section{Clean Cities Annual Metrics Report 2006}

P. Bergeron and V. Putsche

Prepared under Task No. FC07.2200

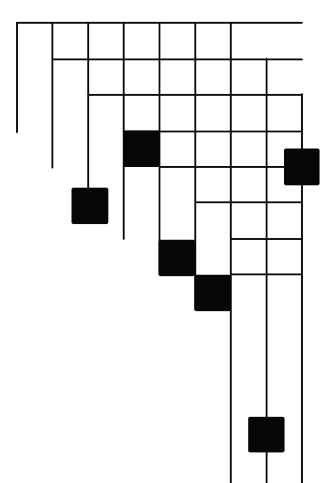

National Renewable Energy Laboratory

1617 Cole Boulevard, Golden, Colorado 80401-3393

303-275-3000 • www.nrel.gov

Operated for the U.S. Department of Energy

Office of Energy Efficiency and Renewable Energy

by Midwest Research Institute • Battelle

Contract No. DE-AC36-99-G010337 


\section{NOTICE}

This report was prepared as an account of work sponsored by an agency of the United States government. Neither the United States government nor any agency thereof, nor any of their employees, makes any warranty, express or implied, or assumes any legal liability or responsibility for the accuracy, completeness, or usefulness of any information, apparatus, product, or process disclosed, or represents that its use would not infringe privately owned rights. Reference herein to any specific commercial product, process, or service by trade name, trademark, manufacturer, or otherwise does not necessarily constitute or imply its endorsement, recommendation, or favoring by the United States government or any agency thereof. The views and opinions of authors expressed herein do not necessarily state or reflect those of the United States government or any agency thereof.

Available electronically at http://www.osti.gov/bridge

Available for a processing fee to U.S. Department of Energy and its contractors, in paper, from:

U.S. Department of Energy

Office of Scientific and Technical Information

P.O. Box 62

Oak Ridge, TN 37831-0062

phone: 865.576 .8401

fax: 865.576 .5728

email: mailto:reports@adonis.osti.gov

Available for sale to the public, in paper, from:

U.S. Department of Commerce

National Technical Information Service

5285 Port Royal Road

Springfield, VA 22161

phone: 800.553.6847

fax: 703.605.6900

email: orders@ntis.fedworld.gov

online ordering: http://www.ntis.gov/ordering.htm 


\section{Table of Contents}

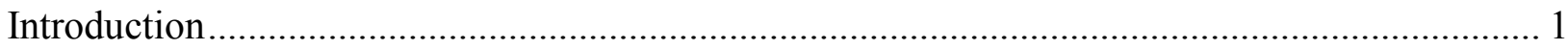

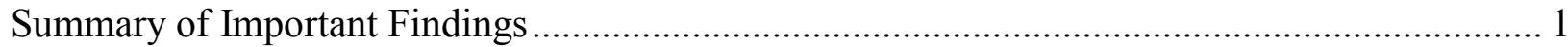

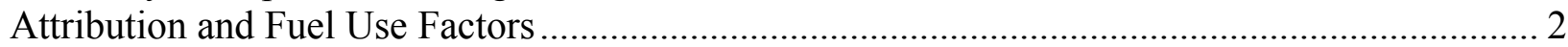

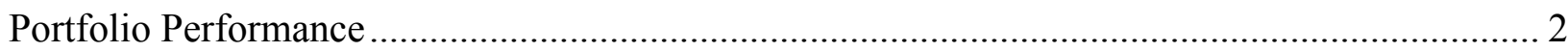

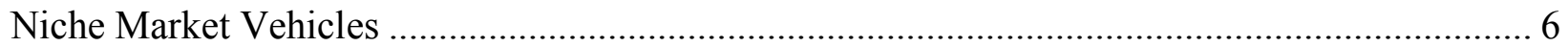

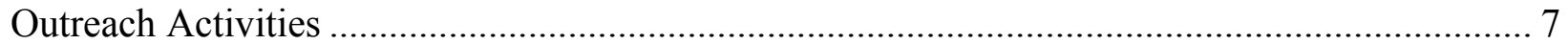

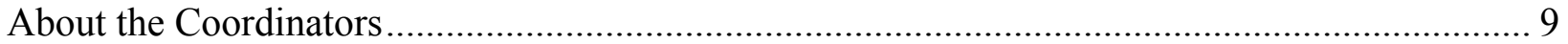

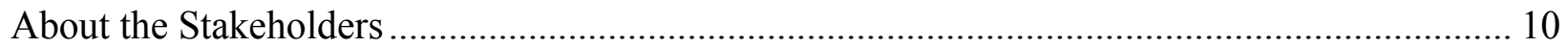

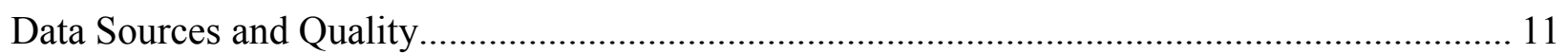

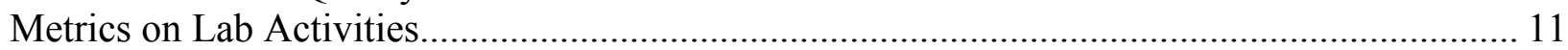

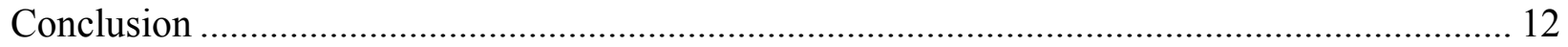

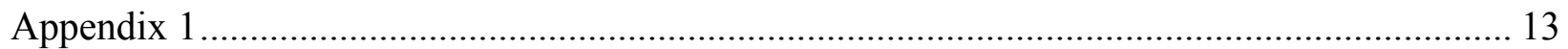

\section{List of Figures}

Figure 1. Projected Clean Cities Displacement Based on 14.5\% Annual Increase ......................... 3

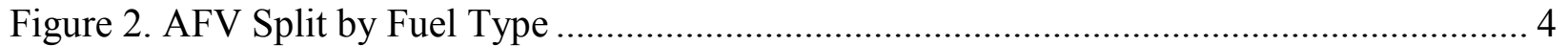

Figure 3. Percentage of AFV Displacement by Each Fuel ............................................................ 4

Figure 4. Displacement in Million Gallons Due to Idle Reduction Projects ................................. 5

Figure 5. Percentage of Total AFVs and HEVs by Niche Market................................................ 7

Figure 6. Split of Outreach Activities among Audience Types .................................................... 8

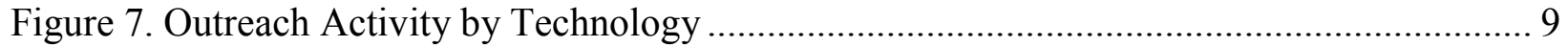

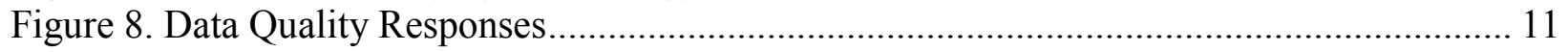

\section{List of Tables}

Table 1. Gasoline Displacement of Each Portfolio Element ......................................................... 2

Table 2. Number and Type of Vehicles for Each Niche Market ...................................................... 6

Table 3. Number of Coalitions with Projects that Include Non-Road Vehicles or Equipment ..... 7

Table 4. Results for the Six Types of Outreach Activities .......................................................... 8

Table 5. Breakdown of Grants by Value and Number............................................................. 10

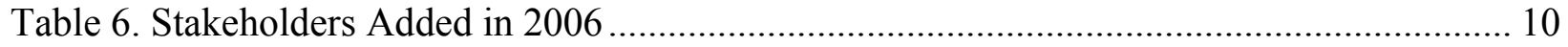

Table 7. Numbers of Private Stakeholders Affiliated with Coalitions ......................................... 10 


\section{Introduction}

Each year the U.S. Department of Energy (DOE) asks Clean Cities coordinators to submit an annual report of their activities and accomplishments for the previous calendar year. Data and information are submitted to an online database that is maintained as part of the Alternative Fuels Data Center at the National Renewable Energy Laboratory (NREL). Coordinators submit a range of data that characterize the membership, funding, projects, and activities of their coalitions. They also submit data about sales of alternative fuel blends, deployment of alternative fuel vehicles (AFVs), hybrid electric vehicles (HEVs), idle reduction initiatives, and fuel economy activities. NREL analyzes the data and translates them into gasoline reduction impacts, which are summarized in this report.

For 2006, 80 of the 85 coalitions that were active throughout 2006 submitted their reports - a response rate of $94 \%$. This is up from the 2005 report response rate of $70 \%$. Appendix 1 lists the coalitions that submitted their 2006 reports by the May 15, 2007, deadline. Coalition coordinators assemble the data based on voluntary reports from their stakeholders - the private and public entities that members of the coalitions. As such, these reports represent a subset of the activities going on throughout the nation, but are an important indicator of the impact of the coalitions and of the priorities at the local level.

In addition to the coordinator reports, metrics are gathered about activities funded by the Clean Cities Program at NREL and Oak Ridge National Laboratory (ORNL). NREL provides a range of technical data, tools, and resources to support coalitions in their efforts to accelerate the use of alternative fuels and other technologies in the Clean Cities portfolio. ORNL produces the Fuel Economy Guide and provides a range of public information related to fuel economy. These metrics are also presented in this report.

\section{Summary of Important Findings}

About 375 million gallons of gasoline were displaced ${ }^{1}$ through the Clean Cities efforts in 2006 $50 \%$ more than in 2005. This displacement represents the combined results of the activities reported by coalitions as analyzed by NREL, and the impacts of the Fuel Economy Guide and related activities as estimated by ORNL.

At $71 \%$, AFVs once again accounted for the largest share of the total displacement. The use of biofuels (ethanol and biodiesel) as fuels for AFVs and in low-level blends displaced 128 million gallons, 34\% of the total 376 million. Fuel economy impacts were responsible for displacing 80 million gallons (combined impacts of coalition and ORNL activity), and idle reduction and HEV technologies combined to displace 16 million gallons of gasoline.

In addition to petroleum displacement, a remarkable achievement of the coalitions is their ability to leverage the DOE investment. In 2006, the coalitions won 165 grants worth a total of $\$ 87.3$ million, plus another $\$ 33.1$ million in leveraged funds from coalition members. This represents a

\footnotetext{
${ }^{1}$ The fuel displaced includes both gasoline and diesel. Fuel displacement in this report has been converted to gasoline gallon equivalents using the lower heating value ratio of the fuels.
} 
15:1 leveraging of the $\$ 8$ million program budget in FY06. This level of funding enabled the coordinators to spend more than 80,000 hours pursuing Clean Cities' goals-like having a national network of 47 full-time technical sales professionals working to reduce U.S. dependence on oil.

Coordinators entered 917 outreach activities for 2006, which were estimated to reach 21 million people. AFVs were most often the subject of these activities, as has generally been the case in the past. As was the case last year, blends were the next most popular outreach subject. More than half of the outreach activities included blends as a target technology.

\section{Attribution and Fuel Use Factors}

In an effort to improve the link between coalition activities and end results, the coalition annual report includes an attribution factor to account for the percentage of a project's outcome that might be due to coalition activities versus those of other participants in the project. This was used in the estimate of impacts for fuel economy, idle reduction, alternative fuel blend, and outreach projects. Coordinators entered the percentage of the project's outcome they thought they were responsible for, and the project's overall outcome was multiplied by that percentage to determine the coalitions' impacts. Although subjective, it does attempt to address the issue of attribution where coalitions are one of multiple partners involved in a project.

This year's coalition report introduced a new option allowing the coordinators to enter the amount of alternative fuel used by the AFVs they reported. If they knew this amount, they could enter it instead of the default values on the form to convert numbers of AFVs reported into an amount of fuel saved.

\section{Portfolio Performance}

Coordinators submitted information on all five technologies in the Clean Cities portfolio. These data were analyzed and converted into an amount of gasoline displaced by each element. As shown in Table 1, about 375 million gallons of gasoline were displaced through Clean Cities efforts in 2006. The coalitions were responsible for 302 million of the total displaced, for an average of 3.8 million gallons per responding coalition. This is $50 \%$ higher than the total 2005 displacement of 250 million gallons.

Table 1. Gasoline Displacement of Each Portfolio Element

\begin{tabular}{|l|c|c|c|}
\hline & $\begin{array}{c}\text { Million } \\
\text { Gallons }\end{array}$ & $\begin{array}{c}\text { Percent of } \\
\text { Total }\end{array}$ & $\begin{array}{c}\text { Change from } \\
\text { Last Year }\end{array}$ \\
\hline AFV & 268 & $71 \%$ & $64 \%$ \\
\hline Fuel Economy & 7 & $2 \%$ & $470 \%$ \\
\hline Fuel Economy - ORNL & 73 & $19 \%$ & $16 \%$ \\
\hline Blends & 10 & $3 \%$ & $17 \%$ \\
\hline Hybrid Electric Vehicles & 9 & $2 \%$ & $137 \%$ \\
\hline Idle Reduction & 8 & $2 \%$ & $-15 \%$ \\
\hline Total & 375 & $100 \%$ & $50 \%$ \\
\hline
\end{tabular}


The $50 \%$ increase in fuel displacement from 2005 is considerably higher than the $16.6 \%$ average annual increase needed to raise the annual displacement from the 2005 total to the 2020 goal of 2.5 billion gallons per year. Because of this, coalitions are on track to reach 3.2 billion gallons gasoline displaced in 2020, exceeding the goal by 700 million gallons.

Figure 1 shows the projected annual gasoline displacement assuming a $16.6 \%$ annual increase starting from the 2006 displacement total of 375 million gallons. It compares this to the previous curve based on the 2005 survey results that projected a 2006 displacement total of 290 million gallons.

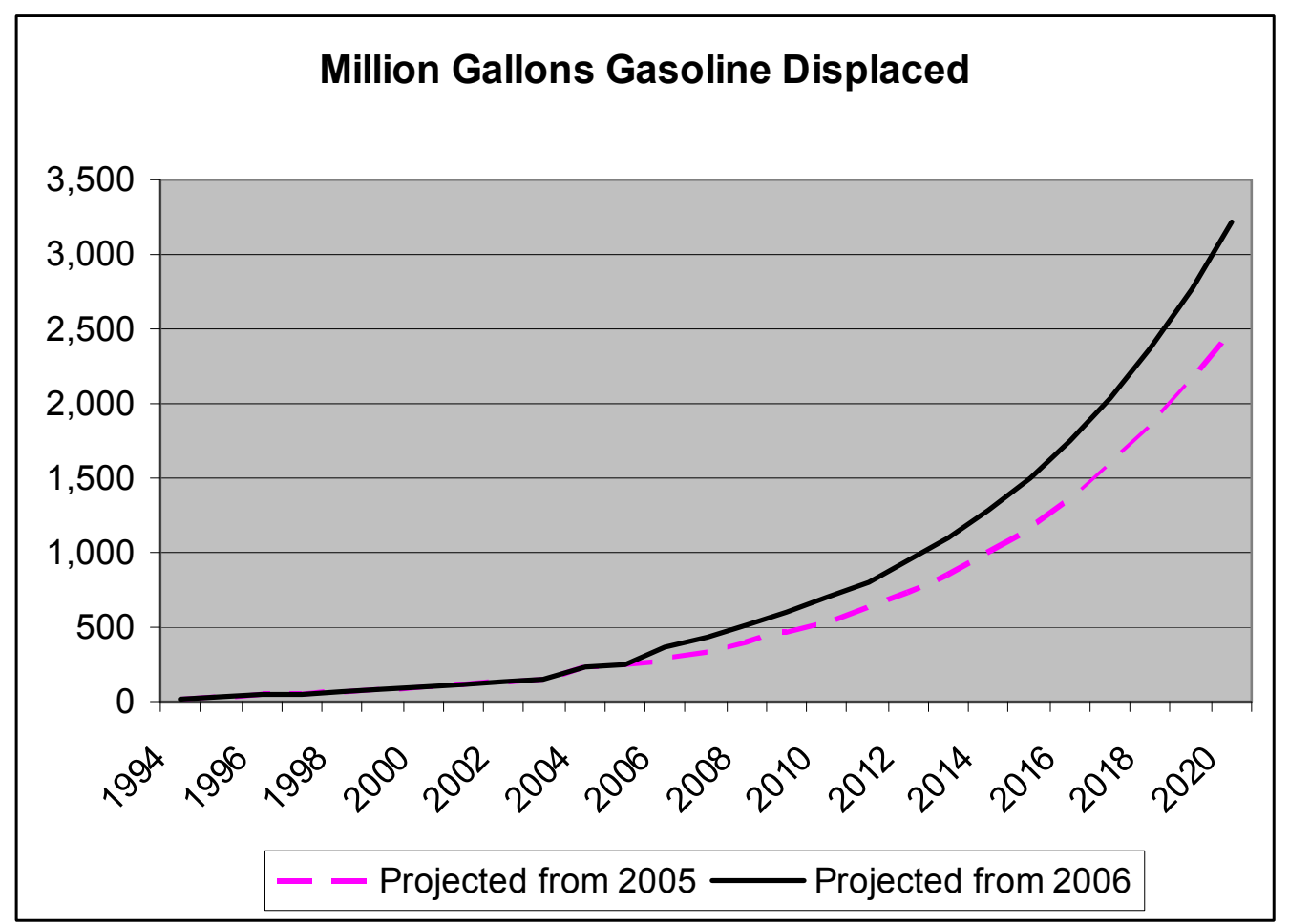

Figure 1. Alternative Displacement Projections Based on 16.6\% Growth from 2006 versus 2005

\section{Alternative Fuel Vehicles}

As shown in Table 1, AFVs accounted for the displacement of 268 million gallons, or $71 \%$ of the total portfolio displacement. This is an increase of $64 \%$ compared to 2005 fuel displacement by AFVs. In 2006, coalitions reported a total of 408,138 AFVs split among the vehicle types, as shown in Figure 3. 


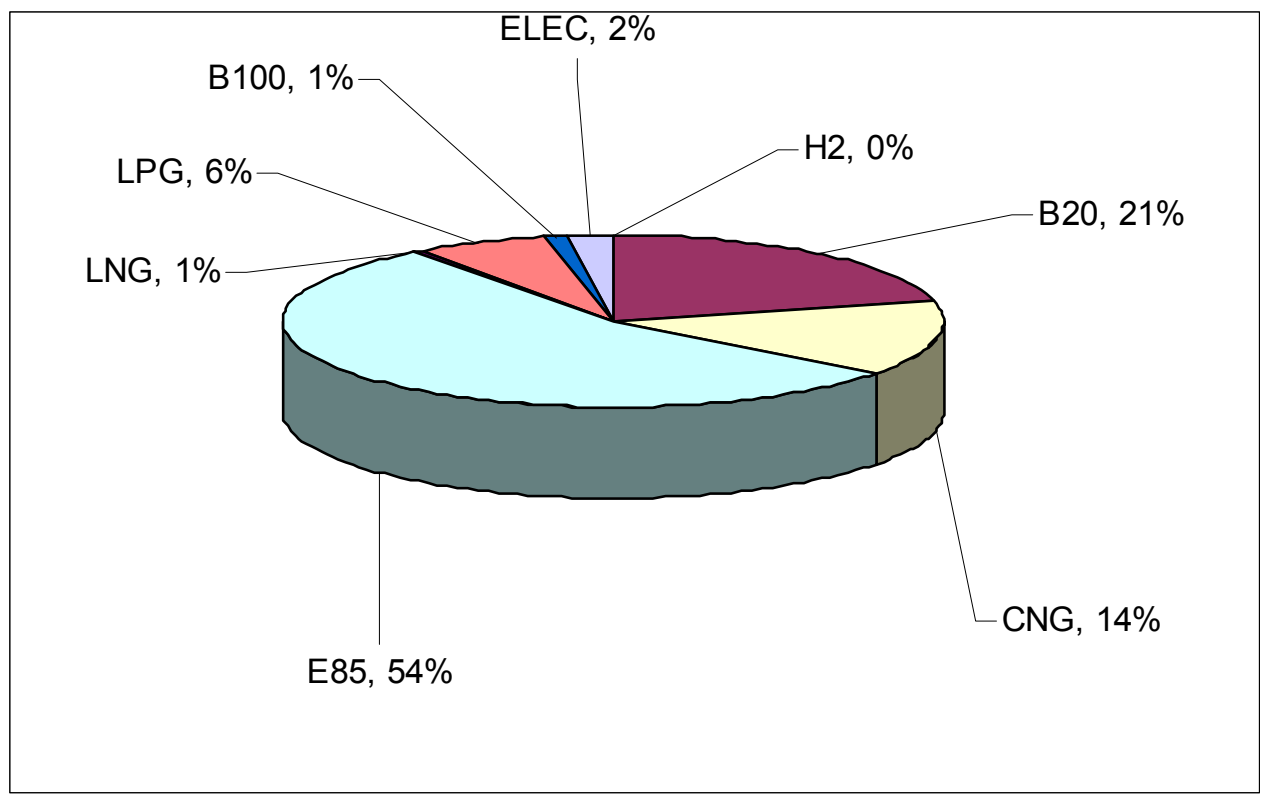

Figure 3. AFV Split by Fuel Type

Figure 4 shows the percentage of the total gallons displaced in AFVs by fuel type. Compressed natural gas $(\mathrm{CNG})$ remains at the top of the list, having accounted for $30 \%$ of the total AFV displacement.

E85 is the next largest contributor with 24\%; biodiesel (B20 and B100) accounted for 23\% of the of the AFV displacement total. Biofuels (E85, B20, and B100) use represents 47\% of the displacement due to AFVs.

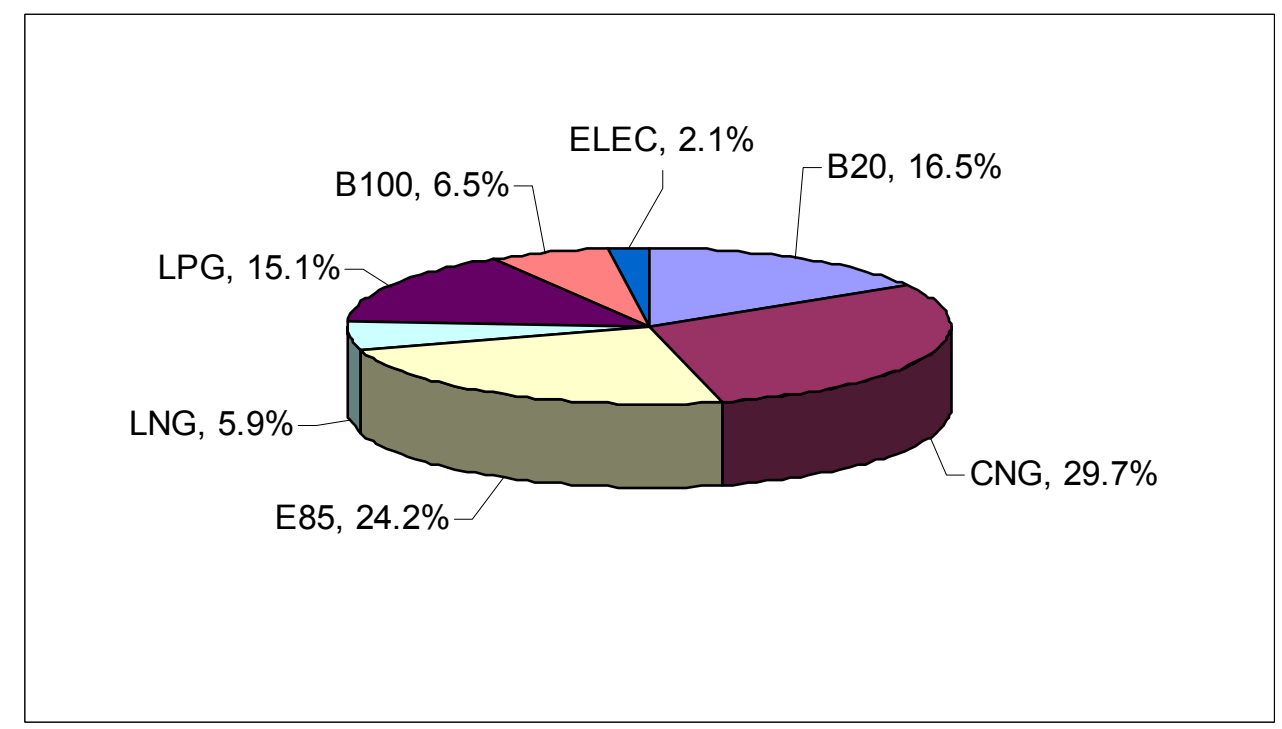

Figure 4. Percentage of AFV Displacement by Each Fuel

Sixty-one percent of the total displacement due to AFVs was from alternative fuel use in heavyduty vehicles. Biodiesel and LNG use is confined almost exclusively to heavy-duty vehicles; 
roughly two-thirds of the displacement from $\mathrm{CNG}$, liquefied petroleum gas (LPG), and electricity results from heavy-duty vehicles.

\section{Fuel Economy}

This year the 2006 questionnaire saw a large increase in displacement from coalition fuel economy projects. This category includes projects to reduce vehicle miles traveled (VMT) as well as improvements in vehicle fuel economies. Eight coalition projects that focused on reducing VMT displaced 1.9 million gallons of gasoline. Another 5.5 million gallons were displaced as a result of five coalition projects to replace lower fuel economy vehicles with higher fuel economy vehicles. On the 2005 questionnaire, coordinators reported only two fuel economy projects, which accounted for 1.5 million gallons displaced.

\section{Idle Reduction}

Estimated fuel displacement for idle reduction technologies reached 8.4 million gallons in 2006 . Idle reduction technologies included truck-stop electrification, onboard idle reduction, and idle reduction policies. As shown in Figure 5, idle reduction policies made up 70\% of the displacement estimated for the three technologies; the rest were spread evenly between onboard idle reduction and truck-stop electrification. Although the number of truck-stop electrification projects increased from 10 to 11, the displacement from truck-stop electrification projects fell by about two-thirds from the 3.5 million gallons displaced in 2005.

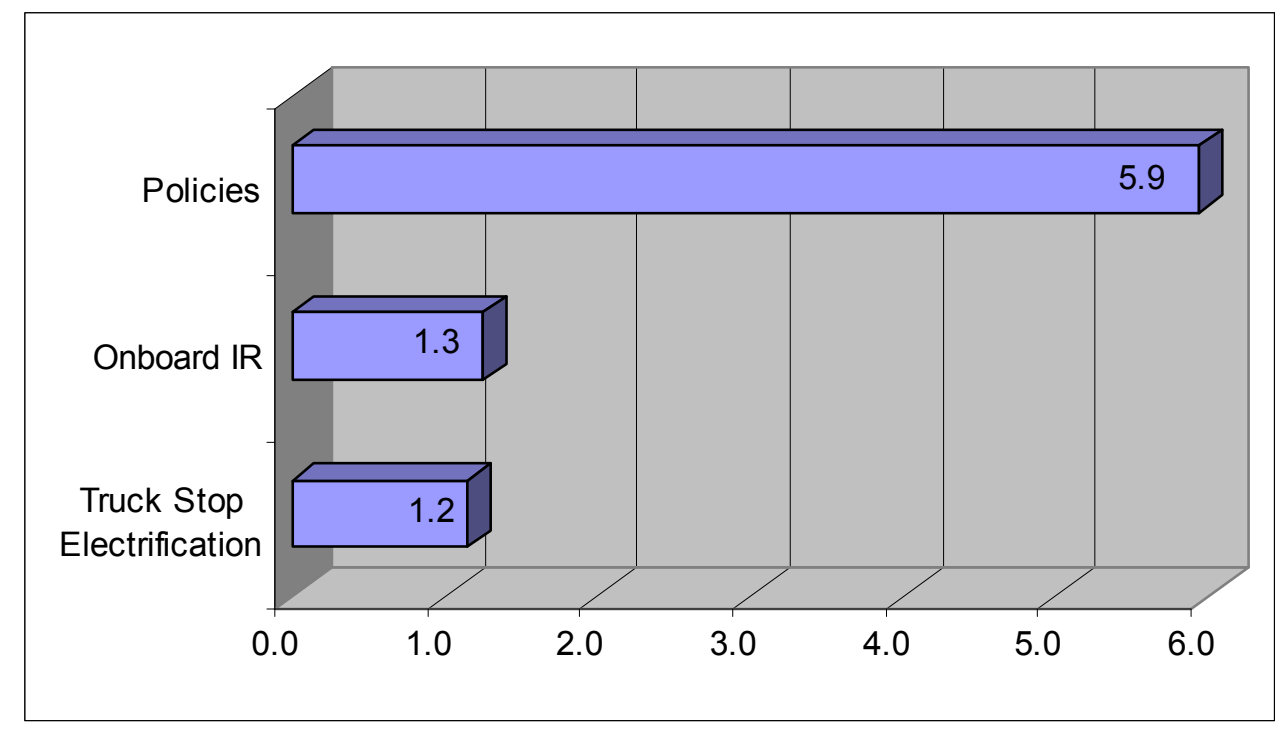

Figure 5. Displacement in Million Gallons Due to Idle Reduction Projects

\section{Blends}

Clean Cities' efforts to promote the use of alternative fuel blends saved 10 million gallons in 2006. The use of low-level biodiesel blends saved roughly 1 million gallons; E10 saved the remaining 9 million gallons. This is a small fraction of the roughly 5 billion gallons of ethanol sold in blends in 2006, but represents what coalitions feel they were influential in getting into the marketplace. 


\section{Hybrid Electric Vehicles}

The number of HEVs resulting from Clean Cities efforts reached 43,886 in 2006, about 10\% of the total vehicles (AFVs plus HEVs) reported in the 2006 questionnaire. Using these vehicles rather than conventional vehicles saved 9 million gallons in 2006, a 137\% increase compared to savings estimated from the 2005 questionnaire. Like fuel economy measures, higher gasoline prices seem to have been a major factor in the increased displacement by HEVs compared to 2005.

\section{Niche Market Vehicles}

The questionnaire also asked coordinators to inventory their AFVs and HEVs in key niche market fleets in their areas. As shown in Table 2 and Figure 6, the transit niche market has the largest number of vehicles and accounts for nearly $54 \%$ of the total niche market vehicle population. Over $90 \%$ of these transit buses run on B20. Overall, B20-capable vehicles account for $63 \%$ of the AFVs in the total niche market vehicle population.

Table 2. Number and Type of Vehicles for Each Niche Market

\begin{tabular}{|l|c|c|c|c|c|c|c|c|c|c|c|c|c|}
\hline \multicolumn{1}{|c|}{ Niche Market } & B20 & B100 & CNG & ELEC & E85 & H2 & HYB & LNG & LPG & M85 & NEV & PHYB & TOTAL \\
\hline Airport & 124 & 0 & 1,629 & 212 & 0 & 0 & 7 & 122 & 44 & 0 & 76 & 0 & 2,214 \\
\hline Deliv./Transport & 708 & 127 & 1,556 & 106 & 23 & 4 & 1,001 & 47 & 1,970 & 0 & 0 & 0 & 5,542 \\
\hline Local Government LDVs & 1,384 & 0 & 4,851 & 227 & 3,251 & 11 & 3,343 & 0 & 1,909 & 0 & 2 & 0 & 14,978 \\
\hline Maintenance & 71 & 24 & 327 & 0 & 1,314 & 0 & 39 & 0 & 52 & 2 & 190 & 0 & 2,019 \\
\hline Off-road vehicles & 1,607 & 425 & 0 & 399 & 0 & 0 & 0 & 0 & 116 & 0 & 115 & 0 & 2,662 \\
\hline Other Government & 3,775 & 68 & 1,492 & 100 & 7,123 & 5 & 115 & 60 & 486 & 0 & 563 & 0 & 13,787 \\
\hline Police & 1 & 0 & 1,901 & 13 & 2 & 0 & 18 & 0 & 21 & 0 & 5 & 0 & 1,961 \\
\hline School Bus & 9,620 & 0 & 631 & 0 & 0 & 0 & 0 & 0 & 909 & 1 & 0 & 0 & 11,161 \\
\hline Shuttle & 87 & 13 & 487 & 14 & 0 & 0 & 17 & 0 & 812 & 0 & 0 & 0 & 1,430 \\
\hline Transit & 66,640 & 339 & 2,532 & 11 & 0 & 0 & 462 & 1,361 & 705 & 0 & 0 & 1 & 72,051 \\
\hline US Parks & 7 & 120 & 15 & 10 & 2 & 0 & 10 & 0 & 1 & 0 & 31 & 0 & 196 \\
\hline USPS & 0 & 0 & 428 & 22 & 1,350 & 0 & 0 & 0 & 0 & 0 & 0 & 0 & 1,800 \\
\hline Utility & 223 & 0 & 1,107 & 17 & 636 & 0 & 13 & 0 & 121 & 0 & 2 & 0 & 2,119 \\
\hline Waste haulers & 56 & 6 & 200 & 0 & 0 & 0 & 0 & 887 & 28 & 0 & 0 & 0 & 1,177 \\
\hline Total & 84,303 & 1,122 & 17,156 & 1,131 & 13,701 & 20 & 5,025 & 2,477 & 7,174 & 3 & 984 & 1 & 133,097 \\
\hline
\end{tabular}




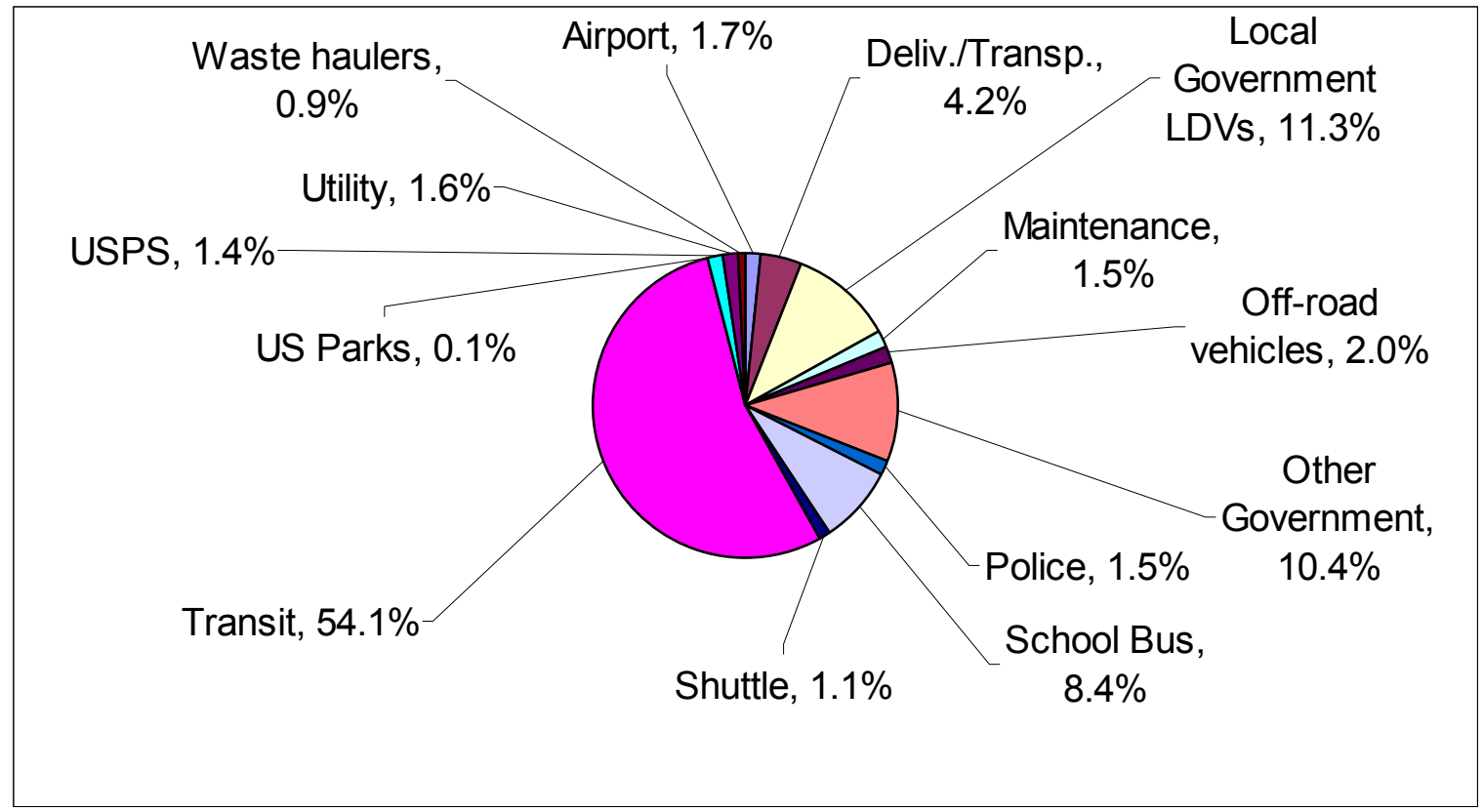

Figure 6. Percentage of Total AFVs and HEVs by Niche Market

Coalitions were asked what type of non-road equipment or vehicles they had used in their projects. They were provided six categories of vehicles/equipment from which to choose: planes, railroads, ships, forklifts, construction, recreation, and other. Responses broke down as shown in Table 3.

Table 3. Number of Coalitions with Projects that Include Non-Road Vehicles or Equipment

\begin{tabular}{|l|c|}
\hline \multicolumn{1}{|c|}{ Category } & Number of Coalitions \\
\hline Planes & 2 \\
\hline Railroads & 6 \\
\hline Ships & 4 \\
\hline Forklifts & 8 \\
\hline Construction & 16 \\
\hline Other & 24 \\
\hline
\end{tabular}

\section{Outreach Activities}

Outreach activities were classified into seven categories (see Table 4). A total of 917 activities were reported and were estimated to reach 21 million people. Media events accounted for $72 \%$ of the total people reached; advertising and Advancing the Choice events accounted for the next highest totals. These numbers do not necessarily reflect the actual impact each event had on the audience. For example, extended personal contact at an Advancing the Choice event may have a much greater impact than an advertisement heard on the radio. 
Table 4. Results for the Six Types of Outreach Activities

\begin{tabular}{|l|c|c|c|c|}
\hline \multicolumn{1}{|c|}{ Activity Type } & $\begin{array}{c}\text { Persons } \\
\text { Reached }\end{array}$ & \# of Entries & $\begin{array}{c}\text { \% of People } \\
\text { Reached }\end{array}$ & $\begin{array}{c}\text { \% of Total } \\
\text { Entries }\end{array}$ \\
\hline Advertisement & $2,896,569$ & 25 & $13.85 \%$ & $3 \%$ \\
\hline Advancing the Choice & $1,578,565$ & 131 & $7.55 \%$ & $14 \%$ \\
\hline Legislation & 5,572 & 29 & $0.03 \%$ & $3 \%$ \\
\hline Literature Distribution & 937,551 & 144 & $4.48 \%$ & $16 \%$ \\
\hline Media Event & $15,089,130$ & 158 & $72.16 \%$ & $17 \%$ \\
\hline Meeting & 83,035 & 408 & $0.40 \%$ & $44 \%$ \\
\hline Web site & 320,999 & 22 & $1.54 \%$ & $2 \%$ \\
\hline Total - All Types & $20,911,421$ & 917 & $100 \%$ & $100 \%$ \\
\hline
\end{tabular}

Coordinators were asked to judge how much they thought they were responsible for each event's number of persons reached versus the contributions of other event sponsors and participants. Analysis of the responses shows that coordinators felt they were responsible for $80 \%$ of the 21 million persons reached.

Figure 7 illustrates the types of audiences the 917 outreach activities attempted to reach. Any one activity could be aimed at more than one audience, and in fact about half of the activities featured multiple technologies. The general public was most often cited as a target audience, followed by government officials and fleets in general. Specialized applications - airports, waste management, delivery trucks, utility trucks, and public transport-were identified as audiences in $15 \%$ to $27 \%$ of the outreach activities. Other audiences were cited as audience types in $33 \%$ of the activities reported.

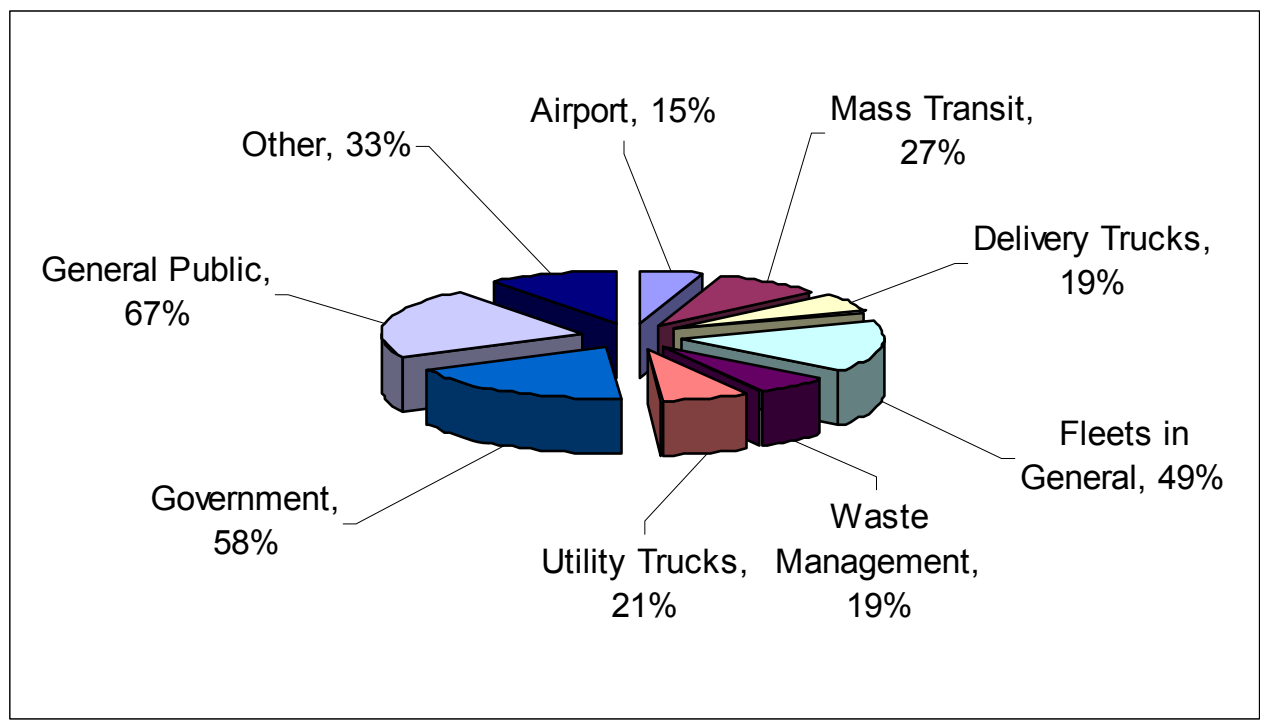

Figure 7. Split of Outreach Activities among Audience Types

Figure 8 shows that AFVs were most often the technology targeted during outreach activities. This has generally been the case in the past. In general, the split among the technologies listed as targets are very similar this year to the results from the 2005 questionnaire. 


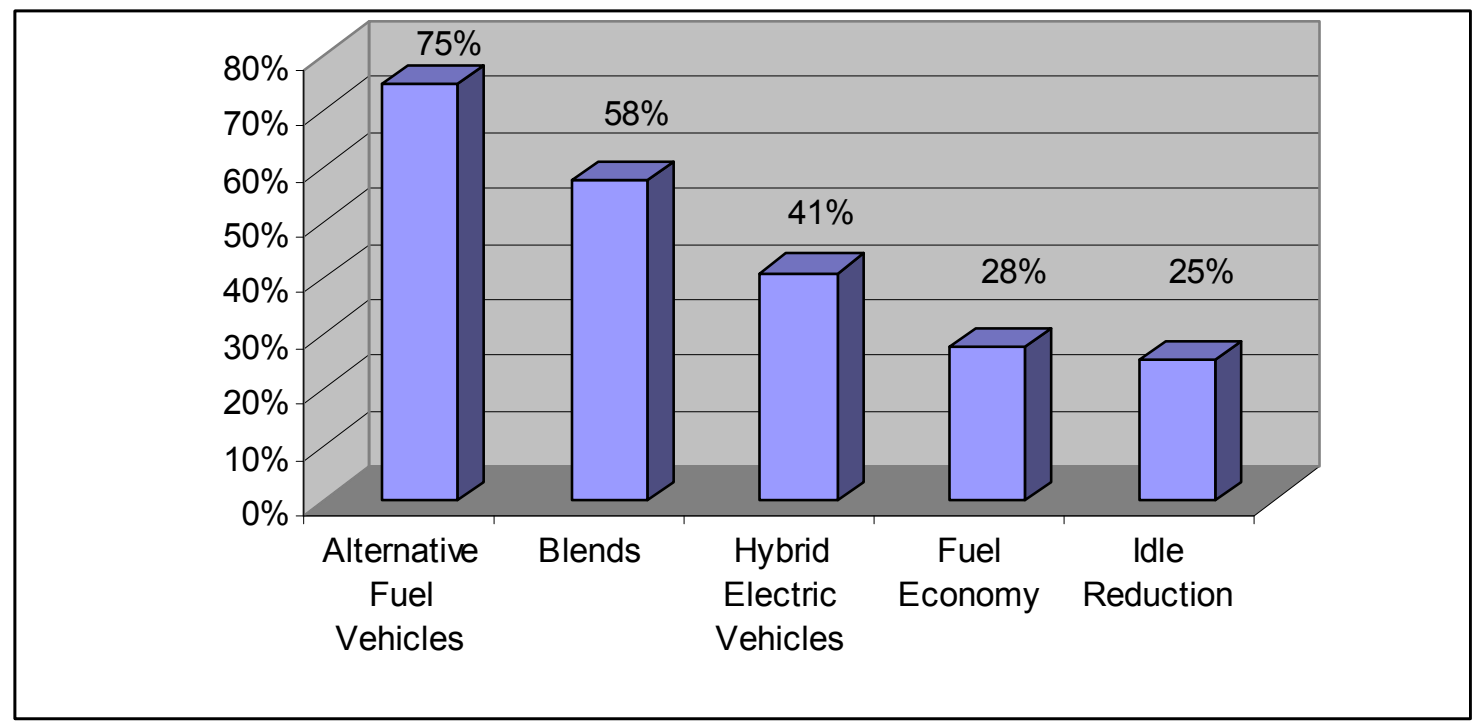

Figure 8. Percentage of Outreach Activities that Included Each Technology

\section{About the Coordinators}

Coordinators reported spending a total of 1,636 hours per week on Clean Cities tasks. The average weekly time spent on Clean Cities business was 22 hours, and the median amount of time was 20 hours per week. Information on coordinator experience was also gathered in the questionnaire. On average, coordinators have been on the job for 4.9 years. Half have had more than 4 years and half had 4 or fewer years of experience. The longest serving coordinator has accumulated 14 years experience. If all 85 coalition coordinators worked 22 hours per week on Clean Cities business, almost 98,000 hours were spent promoting the Clean Cities petroleum reduction portfolio. This is equivalent to having a national network of 47 full-time experienced technical sales professionals working to reduce U.S. dependence on oil.

\section{Coalition Grants}

In 2006,60 of the 80 reporting coalitions received 165 grants worth $\$ 87.3$ million. These coalitions also reported garnering another $\$ 33.1$ million in leveraged funds. Of the 165 grants, the value of 14 grants exceeded $\$ 1$ million. The highest-value grant was obtained by the Granite State coalition for $\$ 13.7$ million; the project was awarded another $\$ 2.4$ million in leveraged funding. The funds will be used for AFV and fueling infrastructure projects. The Greater New Haven coalition was awarded a grant for $\$ 13.1$ million, with another $\$ 7.4$ million in leveraged funds. This grant was for a fuel cell bus demonstration project.

Table 5 presents the breakdown of the value and number of grants reported by the coalitions. 
Table 5. Breakdown of Grants by Value and Number

\begin{tabular}{|l|c|c|c|c|}
\hline & Number & $\begin{array}{c}\text { \% of } \\
\text { Total }\end{array}$ & Total Value & \% of Grand Total \\
\hline$<\$ 50,000$ & 85 & $52 \%$ & $\$ 1,322,346$ & $2 \%$ \\
\hline$\$ 50,000-\$ 99,999$ & 20 & $12 \%$ & $\$ 1,226,594$ & $1 \%$ \\
\hline$\$ 100,000-\$ 499,999$ & 33 & $20 \%$ & $\$ 7,120,689$ & $8 \%$ \\
\hline$\$ 500,000-\$ 999,999$ & 13 & $8 \%$ & $\$ 7,283,498$ & $8 \%$ \\
\hline$\$ 1,000,000+$ & 14 & $8 \%$ & $\$ 70,395,261$ & $81 \%$ \\
\hline Grand Total & 165 & & $\$ 87,348,388$ & \\
\hline
\end{tabular}

\section{About the Stakeholders}

Clean Cities is voluntary, and coalitions draw local stakeholders from the public and private sectors. Stakeholders include local, state, and federal agencies; public health and transportation departments; transit agencies and other government offices; as well as auto manufacturers, car dealers, fuel suppliers, public utilities, and professional associations. A total of 5,452 stakeholders were reported by the 80 coalitions that submitted reports. Of these, 590 were added during 2006.

Table 6 illustrates the number of stakeholders added by coalitions in 2006. Seventy-seven percent of the reporting coalitions added at least one new stakeholder and $43 \%$ added more than five new stakeholders.

Table 6. Stakeholders Added in 2006

\begin{tabular}{|l|c|c|}
\hline \multicolumn{1}{|c|}{ Number Added } & $\begin{array}{c}\text { Number of } \\
\text { Coalitions }\end{array}$ & $\begin{array}{c}\text { Percentage of } \\
\text { Total }\end{array}$ \\
\hline None added or not reported & 18 & $23 \%$ \\
\hline $1-5$ added & 28 & $35 \%$ \\
\hline $6-10$ added & 19 & $24 \%$ \\
\hline More than 10 added & 15 & $19 \%$ \\
\hline Total: & 80 & \\
\hline
\end{tabular}

Coalitions reported 2,716 private stakeholders in $2006-50 \%$ of the total stakeholders. Table 7 shows how this total was apportioned among the coalitions. Two-thirds of the reporting coalitions had more than 10 private stakeholders as of the end of 2006.

Table 7. Numbers of Private Stakeholders Affiliated with Coalitions

\begin{tabular}{|c|c|c|}
\hline Private Stakeholders & $\begin{array}{l}\text { Number of } \\
\text { Coalitions }\end{array}$ & $\begin{array}{c}\text { Percentage of } \\
\text { Total }\end{array}$ \\
\hline 0-10 stakeholders & 26 & $33 \%$ \\
\hline 11-25 stakeholders & 26 & $33 \%$ \\
\hline 26-50 stakeholders & 17 & $21 \%$ \\
\hline More than 50 Stakeholders & 11 & $14 \%$ \\
\hline Total & 80 & $\mathrm{n} / \mathrm{a}$ \\
\hline
\end{tabular}




\section{Data Sources and Quality}

A couple of questions relating to coordinator sources and data quality were added to the questionnaire last year. Gathering the data is always challenging for the coordinators, as they rely on the voluntary reporting of their stakeholders and members. In these questions, coordinators were asked to rate the quality of their data as excellent, good, fair, or poor. Figure 9 presents the response breakdown for the 80 coordinators who answered the question. Forty-nine percent of the respondents classified their data as good, $31 \%$ as fair, $19 \%$ as excellent, and $1 \%$ as poor.

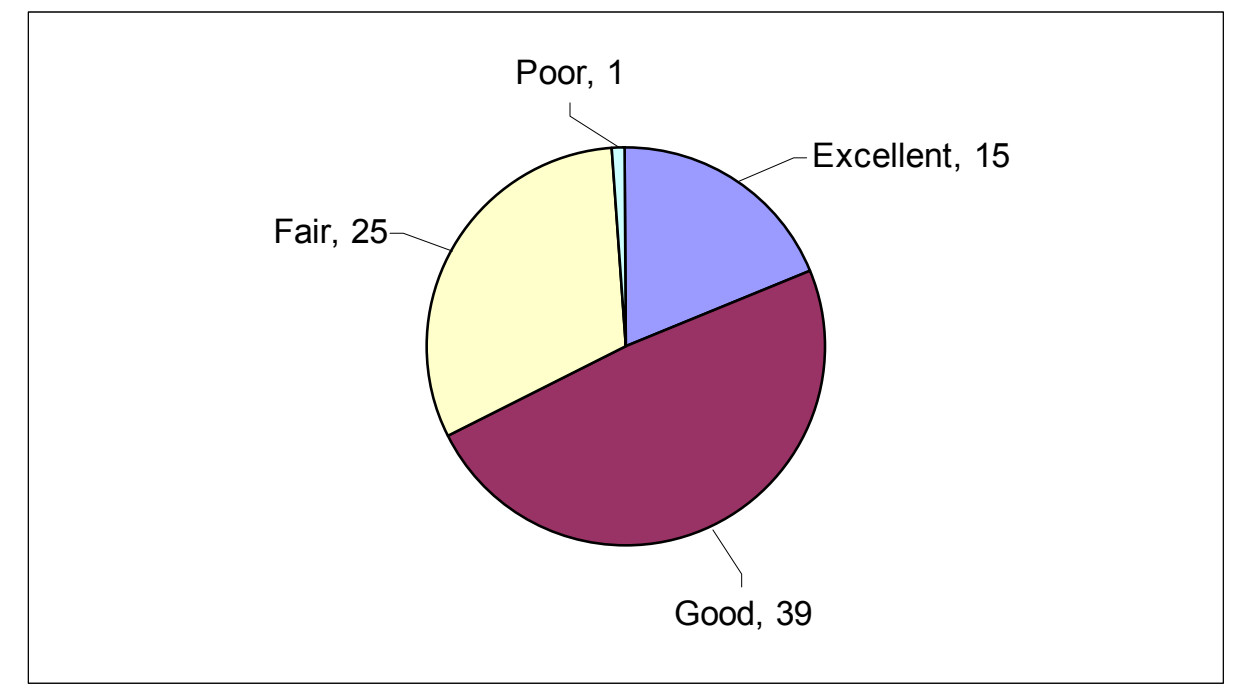

Figure 9. Data Quality Responses

Coordinators were also asked where they obtained their data. They could choose one or more of the following: paper or electronic questionnaires to stakeholders, phone questionnaires of stakeholders, coalition records, or estimates. Cross-correlation of these data with the data quality data showed that the least effective data collection method was using estimates; the quality of the other three methods was similar to each other.

\section{Metrics on Lab Activities}

Both NREL and ORNL track the use of their information and resources. On behalf of Clean Cities, ORNL produces the Fuel Economy Guide based on fuel economy data developed by the Environmental Protection Agency. In addition, ORNL produces the www.fueleconomy.gov Web site, along with other print and educational activities related to fuel economy. Based on the distribution and use of these products and assumptions about their impact on consumer behavior, ORNL estimated the impact of the materials on new car buyers, used car buyers, and car drivers exposed to Clean Cities products and projects resulted in a savings of 73 million gallons. The 73 million gallons is just the impact estimated for 2006. As evidence of increasing concern over higher fuel prices, the annual 2006 savings are 16\% higher than those estimated for 2005.

Use of online resources at NREL also increased dramatically in 2006, and this trend has continued. During 2006, 9.5 million pages of information were accessed by users on the Clean 
Cities and Alternative Fuel Data Center Web sites - a 58\% increase over last year's figure of 6 million. The sites at www.eere.energy.gov/cleancities and www.eere.energy/afdc provide a range of resources to support coordinators, fleets, businesses, and local decision-makers in their efforts to implement the technologies of the Clean Cities portfolio. Site content includes technical data, success stories, publications, and industry contacts, along with databases of federal and state incentives and laws, fuel station locations, available vehicles, and other information.

\section{Conclusion}

The metrics produced by Clean Cities help quantify the impact of the program as a whole, and of the activities of individual coordinators. Clean Cities believes the calculated impacts are a conservative measure of the program impact, because the ability of coordinators to gather specific data about the impact of their activities is, by its nature, limited. The ripple effect of their efforts in their local communities is difficult to measure. Clearly, the support of DOE and the laboratories enables coordinators to serve as local leaders to help leverage the efforts of otherwise disparate groups and funding sources to make more rapid progress in displacing petroleum than would otherwise be possible. 


\title{
Appendix 1
}

Coalitions that Reported for 2006 (as of May 15, 2007)

\author{
Alamo Area \\ Ann Arbor Area Clean Cities Coalition \\ Antelope Valley \\ Baton Rouge \\ Capital Clean Cities of Connecticut, Inc. \\ Capital District (Albany) \\ Central Arkansas \\ Central Coast Clean Cities Coalition \\ Central Indiana Clean Cities Alliance, Inc. \\ Central New York \\ Central Oklahoma Clean Cities \\ Centralina Clean Fuels Coalition \\ Chicago Area Clean Cities \\ Clean Cities - Atlanta \\ Clean Cities of Middle Tennessee \\ Clean Fuels Ohio \\ Colorado Springs Clean Cities Coalition \\ Columbia-Willamette, Inc. \\ Commonwealth Clean Cities Partnership \\ Dallas/Ft Worth \\ Denver \\ Detroit Area Clean Cities \\ East Bay \\ East Tennessee Clean Fuels Coalition \\ East Texas Coalition \\ Florida Space Coast Coalition \\ Genesee Region \\ Gold Coast \\ Granite State Clean Cities Coalition \\ Greater Lansing Area Clean Cities \\ Greater Long Island, Inc. \\ Greater New Haven Clean Cities, Inc. \\ Greater Philadelphia Clean Cities Program \\ Hampton Roads Clean Cities Coalition \\ Honolulu Clean Cities \\ Houston \\ Iowa Clean Cities Coalition \\ Kansas City Regional Clean Cities Coalition \\ Land of Enchantment Clean Cities Corridor \\ Las Vegas, Inc. \\ Long Beach \\ Los Angeles (City) Clean Cities Coalition
}


Maine Clean Communities

Maryland Clean Cities

Massachusetts

Metropolitan Washington Council of Governments

Middle Georgia Clean Cities Coalition

New York City

Northeast Ohio Clean Fuels Coalition

Northern Colorado Clean Cities

Norwich Clean Cities Coalition

Ocean State Clean Cities Coalition

Palmetto State Clean Fuels Coalition

Pittsburgh

Puget Sound Clean Cities Coalition

Red River Valley - Canada

Red River Valley/Winnipeg Manitoba

Rogue Valley

San Diego Clean Fuels Coalition

San Francisco

San Joaquin Valley

South East Texas Clean Cities Coalition

South Shore Clean Cities, Inc.

Southern California Association of Governments

Southwestern Connecticut Clean Cities

St. Louis Regional Clean Cities

State of Delaware

State of Vermont

Treasure Valley

Triangle Clean Cities Coalition

Truckee Meadows, Inc. (Reno)

Tucson

Twin Cities

Utah Clean Cities

Valley of the Sun Clean Cities Coalition

West Virginia Clean State Program

Western New York, Inc.

Western Riverside County Clean Cities Coalition

Wisconsin Clean Cities - Southeast Area, Inc.

Yellowstone-Teton Clean Energy Coalition 


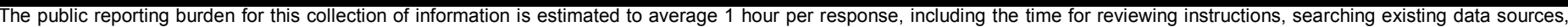

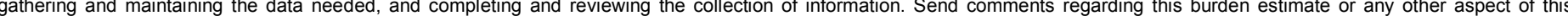

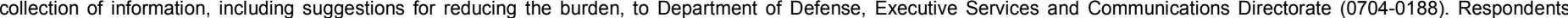

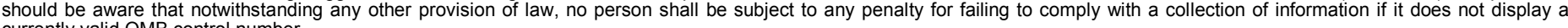
currently valid OMB control number.

PLEASE DO NOT RETURN YOUR FORM TO THE ABOVE ORGANIZATION.

\section{REPORT DATE (DD-MM-YYYY) July 2007}

4. TITLE AND SUBTITLE

Clean Cities Annual Metrics Report 2006
3. DATES COVERED (From - To)

5a. CONTRACT NUMBER

DE-AC36-99-GO10337

5b. GRANT NUMBER

5c. PROGRAM ELEMENT NUMBER

5d. PROJECT NUMBER

NREL/TP-540-41753

5e. TASK NUMBER

FC07.2200

5f. WORK UNIT NUMBER

7. PERFORMING ORGANIZATION NAME(S) AND ADDRESS(ES)

National Renewable Energy Laboratory

1617 Cole Blvd.

8. PERFORMING ORGANIZATION REPORT NUMBER

Golden, CO 80401-3393

NREL/TP-540-41753

9. SPONSORING/MONITORING AGENCY NAME(S) AND ADDRESS(ES)

10. SPONSOR/MONITOR'S ACRONYM(S) NREL

11. SPONSORING/MONITORING AGENCY REPORT NUMBER

\section{DISTRIBUTION AVAILABILITY STATEMENT}

National Technical Information Service

U.S. Department of Commerce

5285 Port Royal Road

Springfield, VA 22161

\section{SUPPLEMENTARY NOTES}

14. ABSTRACT (Maximum 200 Words)

Report summarizes Clean Cities coalition accomplishments, including membership, funding, sales of alternative fuel blends, deployment of AFVs and HEVs, idle reduction initiatives, and fuel economy activities.

\section{SUBJECT TERMS}

Clean Cities; alternative fuel vehicles; AFVs; hybrid electric vehicles; HEVs; deployment; alternative fuel blends; idle reduction; fuel economy; coalitions; coordinators

\begin{tabular}{l}
\hline 16. SECURITY CLASSIFICATION OF: \\
\begin{tabular}{l|l|l|}
\hline a. REPORT & b. ABSTRACT & c. THIS PAGE \\
Unclassified & Unclassified & Unclassified \\
& & \\
\hline
\end{tabular}
\end{tabular}

17. LIMITATION
OF ABSTRACT
UL

18. NUMBER
OF PAGES

19a. NAME OF RESPONSIBLE PERSON

19b. TELEPONE NUMBER (Include area code) 